\title{
Contextual Factor Affecting Health Quality among Female Prisoners in Semarang
}

\author{
Alvy Nur Hidayati'), Hermanu Joebagyo²), Bhisma Murti¹) \\ 1)Masters Program in Public Health, Universitas Sebelas Maret \\ 2)Faculty of Teaching and Educational Sciences, Universitas Sebelas Maret
}

\begin{abstract}
Background: Health law number 36 of 2009 article 4 states that everyone has the right to be healthy. The right applies to all people, including the prisoners even though they have broken the law. This study aimed to describe the quality of health of female prisoners in obtaining health services during detention in Semarang's female prison.

Subjects and Method: This was a qualitative study with a single fixed case study research strategy. The study was conducted in November 2018. The key informants were 4 female prisoners, 1 health policlinic doctor, and 1 head of a correctional institution.

Results: There was a polyclinic unit that provided health services. Prisoners were not sure that health services are often given drugs that do not provide benefits optimally. Health personnel are always prepared to provide health services outside of working hours even though the number of health personnel is limited. Referral is done by conducting a basic examination to obtain an initial diagnosis to determine the next action, referral is done with the permission of members of the correctional observer team (TPP) and the head of the prison then referral can be done at facilities that have collaborated and have MOUs with prison so that prisoners do not pay for treatment. The availability of food and beverages consumed is provided in sufficient quantities. The availability of sports facilities to support health, as well as maintaining personal hygiene of prisoners is carried out by bathing, washing clothes, cleaning beds, and disposing of sanitary napkins in the places provided.
\end{abstract}

Conclusion: The lack of health personnel causes sub-optimal health services. The lack of effectiveness of the drugs causes convictions of prisoners with health services provided in prisons.

Keywords: quality of health, female prisoners

\section{Correspondence:}

Alvy Nur Hidayati. Masters Program in Public Health, Universitas Sebelas Maret. Jl. Ir. Sutami No. 36 A, Surakarta, Central Java. Email: alvynurhidayati@gmail.com. Mobile: o81328353336

\section{BACKGROUND}

Paragraph VI of the 1945 Constitution that the state aims to provide public welfare. Everyone has the same right to get welfare, even an inmate, even though they have broken the law (Mertokusumo, 2007)

In Health Act No. 36 of 2009 article 4 that everyone has the right to be healthy. Even though they are in a correctional institution, a woman has special needs to maintain health, because the possibility of women is at greater risk of health problems compared to men. So this should be a concern for the health needs of female prisoners (Sayrani, 2017).

The 1945 Constitution of the Republic of Indonesia Article 28H Paragraph 1 states that every person has the right to live in physical and spiritual prosperity, to live and obtain a good and healthy environment and the right to receive health services. Failure to meet needs will result in homeostatic imbalances and can cause humans to get sick (Mubarak, 2007).

Some female prisoners stated that there are a number of obstacles in accessing 
health services in prisons, namely difficulties accessing drugs, lack of service staff, lack of care, lack of knowledge about health, and poor planning. These barriers have an impact on stopping treatment, helpless health, poor mental and physical health. Every penitentiary usually has only one medical officer, one doctor and one nurse, although there are several correctional institutions that do not have doctors or no health personnel at all and must rely on monthly visits from doctors who monitor their correctional institutions (Ministry of Justice and Human Rights, 2014).

Harner \& Riley (2013) argued that barriers to limitations and complicated access to health care could result in unresolved health care problems during detention. Plugge, Douglas, \& Fitzpatrick (2008) describe a sense of helplessness that is generated among female prisoners due to the loss of rights to health care.

According to the Minister of Law and Human Rights Yasonna Laoly, it is stated that the number of prisoners in prisons and detention centers increased sharply, with the condition of excess occupancy resulting in the fulfillment of prisoners 'and detainees' rights not being optimal. It is because the facilities and infrastructure as well as the resources to fulfill the needs are not comparable with the number of prisoners and detainees that exist (Asfinawati, 2018).

Correctional Database System Data of the Directorate General of Penitentiary (Ditjen PAS) of the Ministry of Law \& Human Rights in 2017 the average number of female prisoners in semarang female penitentiary amounting to 341 prisoners provided occupancy capacity is 219 thus there is an imbalance of room capacity provided with the number of prisoners causing the Semarang Women's Penitentiary to become overcapacity.
Based on data from preliminary studies obtained in June 2018 from the report of the prison polyclinic there were a number of inmates who experienced illness with a total of 46 inmates with various diagnoses of diseases including HIV, sexually transmitted infections, respiratory tract infections, skin infections, gastrointestinal, cardiovascular infections, diabetes mellitus, teeth and mouth.

In relation with understanding relevant contextuality to describe the relationship as well as the relevance between the quality of health and the fulfillment of health services for female prisoners in the Semarang Women's Penitentiary, the researchersare interested in conducting a study entitled "The Quality of Health for Women Prisoners in Semarang Women's Penitentiary".

\section{SUBJECTS AND METHOD \\ 1. Study design \\ This study employs a qualitative approach with a research strategy using a single fixed case study. The focus of research is real life events and is expected to provide important information about the quality of prisoners' health in prisons that require in-depth explanation and understanding. The sam- pling technique is purposive sampling. The study was conducted at the Women's Penitentiary in November 2018.}

\section{Study informants}

There are several subjects of this study. The first one is the Head of Correctional Institution as the party who knows about the policies, management and implementation set. The second one is the Head of Subdivision of Community and Nursing Guidance as parties who have information as managers and implementers who know how the conditions and conditions and developments in health care providers. The third ones are female inmates were subjects 
who viewed the quality of health and as recipients of health services. Therefore the number of informants in this study consisted of 1 prison chief, 1 doctor in the prison polyclinic, and 4 female prisoners.

\section{Data collection and analysis}

The data were obtained using in-depth interviews, observation, and documentation. The technique of analyzing data is data collection, data presentation, data reduction, data collection conclusions.

\section{RESULTS \\ 1. The availability of polyclinics for inmates who come to get services for complaints suffered}

Based on information obtained from female prisoners with information from health personnel, namely doctors in the prison polyclinic in providing health services, it can be concluded that for prisoners who have complaints of pain in the women's correctional institutions, semarang provides polyclinics to provide health services and treatment.

\section{Confidence in obtaining basic health services at the Correctional Center Polyclinic}

Related to the confidence from female informants who came to the prison polyclinic to get health services, 3 from informants from 4 informants (75\%) who expressed confidence in the provision of health services and medicines as well as 1 informant stated that the services provided were quite convincing but for drugs that given the informant felt confident about it.

3. Readiness of Health Personnel in Providing Health Services

Related to the readiness of health personnel in providing health services at Penitentiary Institutions, all informants (100\%) stated that health personnel always served 24 hours even though they were not always on guard in the prison polyclinic, and if outside working hours found female prisoners who were sick and needed help Immediate action, it means that fellow inmates help confirm the real situation with the block guard officer and block guards will coordinate with the doctor on call to report and take the next step.

\section{The Effectiveness of drugs given according to complaints}

Related to the drug effectiveness given by prison health polyclinics with complaints experienced by female prisoners, 3 out of 4 informants $(75 \%)$ claimed that the drugs given provided benefits for their general complaints, and 1 informant stated that the drugs given just a generic drug that is believed to be unable to provide a cure for the complaints being experienced.

\section{Treatment Payment}

Related to the medical payment system when conducting a medical check-up at the correctional clinic polyclinic, all informants (100\%) stated that they did not pay a fee for medical treatment, and 2 informants stated that those who needed personal expenses were their own desires without recommendations from the prison clinic doctor and medicine purchased outside the prison polyclinic with a prescription from a doctor at the prison clinic or prescription from a doctor outside the prison.

\section{Referral to health facilities out- side correctional institutions}

Related to the eferrals to other health facilities outside the correctional facilities, namely 1 out of 4 informants stated that references had been made to other health facilities outside the correctional facilities because the conditions experienced require further treatment. 3 other informants stated that they only went to the prison polyclinic and never made referrals to health facilities outside the correctional facilities. 


\section{Mantaining Personal Hygiene}

All informants (100\%) stated that there were several ways in which female inmates maintained their personal hygiene, all informants stated that they always cleaned their beds by changing the bed once a week, bathing and washing clothes in the place provided, namely the toilet in in the room or well, and the process of removing sanitary napkins by washing them first and then packing them using crackers or plastic and then throwing them in a closed trash can provided in the room because they feel they have a shared responsibility to maintain cleanliness and health in one room block.

\section{The availability of facilities and desires in maintaining health}

All informants (100\%) stated that the availability of sports facilities to support the health of female prisoners. All the informants stated that the facilities had been provided from prisons, and all informants stated that they wanted to participate in maintaining health such as gymnastics, volleyball, badminton and the like.

\section{Food Feasibility}

Related to the food provided by prisons for female prisoners, all informants (100\%) stated that the taste, cleanliness and variety of menus provided were good enough. The presentation of food using flaps and eating activities is done in each room according to the specified meal times.

\section{The availability of Drinking Water}

Related to the availability of drinking water for female inmates, all informants (100\%) stated that the availability of water was sufficient. The water was available in the prison kitchen and all inmates could take water using special buckets, taking water in turn according to the turn of the pickets. 2 informants stated that they did not consume water provided by the prison and 1 informant said that the water provided by the prison felt bad. Then they decided to buy bottled water in the Koprasi prison.

\section{Licensing/Permission procedures for referral services}

The licensing procedures for referral services outside of prison health facilities from health informants, namely doctors in the prison polyclinic stated that the need for several stages to obtain medical licenses outside prisons for prisoners who are ill, and based on the statement of prison chief informants that permits for referral treatment Outside prison, female prisoners must pass permits and approval from several parties, along with the statement of the head of the women's correctional institution regarding their licensing procedures.

\section{Constraints in providing health service}

In providing optimal health care, health personnel, namely prison polyclinic doctors, have stated the obstacles faced in providing services to all prisoners, namely in providing health services when referral to health facilities outside prisons, which requires sick inmates to be hospitalized. The limited human resources, especially the guard team or security tasked with assisting inmates who were hospitalized, caused prison health personnel to be involved in maintaining and working outside their duties, causing health personnel not able to provide maximum service in the prison polyclinic.

\section{DISCUSSION}

\section{The availability of polyclinics for inmates who come to get services for complaints suffered}

Based on the information obtained, it was concluded that in correctional facilities provided a health service place, namely the prison polyclinic that was used by all female prisoners (informants) to obtain 
health services and treatment. This is in accordance with Nembrini (2007) which states that prisoners or detainees placed within the limitations of the space must have access to health care.

The types of complaints experienced by female prisoners are the history of illness before or during their stay in a correctional institution. This is managed in Law No.12 of 1995 Article 11 letter b concerning Correctional Services stating that as intended in Article 10 paragraph (1) includes a medical examination.

The research shows that a sick condition experienced by a person suffering from a disease, prevention and treatment behavior will increase and tend to seek appropriate treatment if the disease attacked. Someone will seek treatment because they have the desire to recover and reduce the severity of the disease that is experienced and felt then someone will try to find a place of treatment.

\section{Confidence in obtaining basic health services at the Correctional Center Polyclinic}

Most female prisoner informants had positive beliefs about the health services provided in the prison polyclinic. Thus it shows that the positive belief that each female prisoner has on her condition will create positive attitudes and behaviors in receiving the health services provided. This is in line with the Health Belief Model theory proposed by Becker (1997), describing that individuals will take action to avoid, examine or control adverse health conditions if they perceive vulnerability to the condition, if they believe that certain actions available will be beneficial in reducing vulnerability or severity of conditions, and they believe that barriers that are inspired to take action are considered with profit.
The results of this study can be concluded that the belief in the benefits that are positive in obtaining health services carried out will have an impact on one's acceptance of an action for healing themselves, but this must be supported by a good understanding of the treatment process, because if patients feel the benefits of treatment and health services, that will lead to better changes in conditions.

The assumption of the researcher is from an informant's statement regarding the lack of confidence in the health services provided especially in the administration of drugs. It is said that whether a service is appropriate or not, it depends on what is given, namely one of the drugs that complies with the complaint. According to the SOP of Basic Lapas Health Services, the determination of the diagnosis followed by administration of the drug must pass the stage of the complaint history and clinical examination. Researchers understand that this is possible because of the lack of effective communication between doctors and patients (female inmates).

\section{The preparedness of health per- sonnels in providing health services}

Based on the results of interviews, all informants (100\%) stated that health personnels were always prepared to provide health services. This was in accordance with the Basic Health Care Standards for Prisoners in the Prisons. Directorate General of Ministry of Law and Human Rights stated that health services were given in every working day which the opening hour service was according to the policy in each UPT. In Saturdays and Sundays, the guard duty was applied.

The availability and preparedness of health personnels was an important component in providing optimal health services to assisted citizens. An informant 
(doctor) stated that a polyclinic health personnel consisted of 2 health personnels consisting of dentists and nurses and parttime health personnels were consisted of 2 general practitioners who came 2 times a week.Regulation of the Minister of Law and Human Rights of the Republic of Indonesia Number M.HH.02.UM.06.04 of 2011 concerning Health Service Guidelines explained that the standard of the availability of health services in prisons for the number of health personnels needed in health care units (according to conditions) was 1 Doctor, 1 dentist, at 2 nurses, 1 midwife (especially female prisoners), 1 pharmacist assistant , 1 laboratory analyst, 1 nutritionist, and 1 psychologist.

This showed that women's prisons in Semarang did not fulfill the standards of the availability of health services, namely the lack of midwives, pharmacist assistants, laboratory analysts and psychologists. The lack of full-time medical staff has resulted in the difficulty in accessing health services which has led to a lack of maximum use of medical services for prisoners (Lindquist, 1999).

Based on the explanation above, it can be concluded that health personnels were only in prison polyclinic during working hours, which was 07.30-17.00 on MondayFriday, outside the working hours, the health personnles only received health reports through phone to serve consultations if there were female prisoners who got sick, and health personnels would come immediately if an emergency was discovered or occurred outside the working hours. For female prisoners who experience pain in a room, their friends would help by immediately ringing the bell to inform them that there was an emergency. However, there was a lack of health personnels in the field.

\section{The effectiveness of the medicine according to the complaint}

Some informants have positive perceptions related to the effectiveness of the drugs given according to their history of illness and when they experienced an illness.

Prison's health personnel stated that the procedure for administering the drug was in accordance with the function and dosage and in accordance with the procedure for administering drugs to the WBP. Provision of medication was adjusted to the medication schedule per day by giving "one time drink" to avoid the occurrence of drug abuse in the prison.This was in accordance with the Basic Health Care Standards for Prisoners in the Prison. Directorate General of the Ministry of Law and Human Rights RI explained that basic health services for outpatients in providing drugs were according to the indications of disease.

Based on the description above, it can be concluded that someone's perception of the effectiveness of drugs that have a positive impact on the conditions which in accordance with the indications of the disease would affect someone's belief in a given health service. However, this must be supported by a good understanding of the medicinal uses, because if they got the same medicine in every checks and felt that there was no change, then it was possible that the person did not understand the diagnosis of the disease and could lead to cessation of the treatment which would worsen the disease.

The researchers' assumption regarding this matter because they only provided drugs with common diseases in prison, but they did not provide drugs for special diseases. This was because the budget obtained by the prison polyclinic from the regional or central government was quite limited. 


\section{Treatment Payment}

All informants (100\%) stated that they did not pay the treatment costs, because the treatment for both inside and outside the prison was free. Statement of the Head of Correctional Institutions, the distribution of drugs in the prison polyclinic was obtained from drug assistance which obtained from the Community Health Center and also from Budget Implementation Registration Form (BIRF). The system of treatment payment to health facilities outside the referral prison was directed to hospitals that have networks or cooperation with prisons and have an MOU so that they did not have to pay their personal costs, and if they were personally treated in hospitals with their own choice then they must pay the treatment.

This was in accordance with the Basic Health Care Standards for prisoners in the Prisons. Directorate General of the Ministry of Law and Human Rights R.I explained that health financing must be provided to organize and or utilize various health efforts. The funding can come from the government budget, health costs were fully borne by the government, both central and regional, and partly borne by the community, namely the existence of community participation in the implementation of health efforts and the time to utilize health services. To be able to implement health services that were evenly distributed to WBP within the Ministry of Law and Human Rights, the health funding was from government funding sources (budget in Ministries/BIRF), Sources of funds from donors or non-governmental organizations. Healthy Indonesia Card (HIC) through the Social Security Organizing Agency (SSOA) in Contribution Beneficiary (CB).

This research showed that the prisoners were not required to pay the treatment and health services costs in both the prison polyclinic and health facilities outside the prison. However, this can be applied if it was in accordance with the procedure, which was the initial test to determine the diagnosis and subsequent management at the health facilities that have collaborated with prison and already have an MOU. Beyond this condition, the prisoners were required to pay personal medical expenses.

\section{Referral to health facilities outside correctional institutions}

Only 1 out of 3 informants who had been referred beause of a history of hepatic enlargement suffered, the informant stated that he/she was only told that a referral was needed to get further treatment. Head of the Correctional Institution stated that the referral system to other health facilities must go through a doctor's examination of the prison clinic to find out the initial diagnosis and to find out the next steps to take a referral to another health facility, which was a hospital that has a an MOU with the prison.

This was in accordance with Basic Health Care Standards for Prisoners in the Prison. Directorate General of the Ministry of Law and Human Rights stated that emergency treatments conducted in the new WBP in the form of basic handling that can be conducted by health services in prisons or before referral to health facilities outside prisons were wounds, heart and respiratory diseases, attempted suicide, and others. The thing that must be done was to investigate the causes of emergencies, conduct basic emergency handling (if it was not succeed, then the referrals for further treatment must be prepared).

\section{Maintaining Personal Hygiene}

All informants stated that there were several ways in maintaining personal hygiene, all informants stated that they always cleaned their beds by changing the 
bed cover once a week, bathing and washing clothes in the toilet, and the process of removing sanitary pads by washing it first and then packing it by using plastic and then put it in a closed trash in the room because they felt that they have a responsibility to maintain the cleanliness and health in a room. The head of correctional institution stated that the water for bathing and washing hand by using well water in some places was still good and appropriate, and accommodated in water tanks provided in several blocks. This was in accordance with Nembrini (2007) who stated that prisoners or convicts who were placed in limited space must have access to the toilet for bathing and defecating in sufficient quantities.

International instruments that specified the protection of prisoners namely the Minimum Standard Rules for the Treatment of Prisoners (SMR) stated that adequate water and toilet equipment must be provided for personal hygiene so that the prisoners can keep their bodies clean, all the clothes must be cleaned, well maintained, and replaced so that the prisoners could maintain their personal hygienes. The fulfillment of the health rights of female prisoners related to personal hygiene has been included in Rules 12 and 14 of the Standard Minimum Rules for Treatment of Prisoners (SMR) which stated that hygiene installations must be adequate so that each prisoner at the Correctional Institutions can defecate at the required time in a clean and polite manner. Then, the shower must be provided by the Correctional Institutions.

This need to be considered because it can be a trigger for the occurrence of a health problem for female prisoners in the correctional institutions, it was the prisoners' responsibility to maintain the cleanliness of the surrounding environment because they lived together in one block. There were some rules that must be considered in the area of limited space, therefore, it was highly necessary to create conditions to avoid the occurrence of health problems (Nembrini, 2007).

\section{The availability of facilities and desires in maintaining health}

All informants stated that the prison provided facilities to support health, which was the availability of sports fields. This was in accordance with Nembrini (2007) who stated that prisoners who placed in the limited space must have access to sports fields or open spaces.

The doctor in the prison polyclinic stated that one of the preventive efforts in maintaining the health of female prisoners in the Women's Correctional Institution was by providing health facilities that support the participation of prisoners. This was in accordance with Government Regulation No. 32 of 1999, it was explained that one of the health services was preventive measures in the health sector for prisoners and in correctional institutions.

It can be concluded that correctional institutions provided health facility to support health care for female prisoners, namely the availability of sports fields that were used to do several sports activities such as gymnastics, badminton, table tennis and so on. From the interviews with female prisoners, they stated that they always participated in sports activities to support health and to pass their spare time in prison.

\section{Food Feasibility}

All informants stated that the food provided in prisons in terms of taste, cleanliness and variety of the menu was quite good. But the unavailability of nutriationists caused a problem in calculating nutritional value for Women Prison in Semarang. The kitchen coordinator in the 
correctional institution were a midwife and nurse who were not in accordance with their competences. This was not in accordance with the Basic Health Care Standards for Prisoners in the Prison. The Directorate General of Community of the Ministry of Law and Human Rights regarding the standard availability of health services in prisons was the number of health personnels (adjusted to service conditions and occupancy capacity) especially nutritionist was at least 1 person.

One of the theories that can be used in discussing basic needs was Maslow's Hierarchy of Needs Theory. Human needs by Maslow Physiological Needs was a hierarchy of the most basic needs which was the need to be able to live such as eating, drinking, residence, and clothing. Maslow's basic needs theory related to this research showed that food-related physical care was an obligation and responsibility of the Government to fulfill the prisoner's rights (Hamid, 2014).

The statement of the head of the correctional institution stated that the food provided by the prison was suitable for consumption because the menu provided was quite varied and the menu for the 10 days were always different. This was in accordance with the Decree of the Director General of Community of the Ministry of Law and Human Rights of the Republic of Indonesia Number Pas-498.PK.01.07.02 of 2015 concerning the Standards of Food Delivery at Correctional Institutions which explained that the menu framework was a pattern of food use at each meal time which arranged for 1 menu cycle.The menu frame used in Lapas was a menu for every 10 days to find out the intensity of feeding to avoid boredom, easier to find suitable food variations, can calculate the costs needed to eat each month, the daily distribution of menu.
It can be concluded that the food provided was in accordance with the standards and guidelines for the implementation of food for the prisoners. From a variety of food menu, food hygiene and taste was good, but the nutritional value of the food was doubtful because the kitchen supervisor or coordinator was not a nutritionist but a midwife and nurse who were not in accordance with their competence.

\section{Drinking Water Availability}

All informants stated that in correctional facilities, the availability of water was sufficient for the prisoners. The theory that can be used in discussing basic needs was Maslow's Hierarchy of Needs Theory. Maslow's basic needs theory related to this research showed that physical care related to drinking was the obligation and responsibility of the Government to fulfill the rights of the prisoners (Hamid, 2014).

The head of the correctional institution stated that drinking water originating from PAM and the amount of drinking water available in the prison kitchen were always sufficient and suitable for consumption because it has been tested at the Semarang Health Office laboratory. This was in accordance with a study done by Ramidha (2011) which stated that drinking water provided in prisons was obtained from PDAM water sources an the storage stored in the kitchen filled and cooked at all times, and the water was chlorinated before being consumed.

It can be concluded that the drinking water in the prisons were sufficient. The water consumed came from PAM and has gone through a laboratory test process and boiling process before consumption. This was in accordance with a study done by Primawardani (2017) which stated that the provision of drinking water at Correctional Institutions was in accordance with appli- 
Journal of Health Policy and Management (2019), 4(1): 1-12

https://doi.org/10.26911/thejhpm.2019.04.01.01

cable International and National Instruments.

\section{Licensing procedures for referral services}

There were some licensing procedures for referral services outside of prison health facilities from doctors in the prison polyclinic. They stated that it was necessary to provide several stages to obtain medical licenses outside prisons for prisoners who were sick. The head of correctional institution stated that the permits for referral treatment outside prisons for female prisoners must pass the approval from several parties.

This was in accordance with the Basic Health Care Standards for Prisoners in the Directorate General of Community of the Ministry of Law and Human Rights of the Republic of Indonesia. Emergency Management that was conducted to WBP in the prisons was basic health services that can be conducted by health services or before the referral to health facilities outside the prison. Steps for activities including checking the causes of emergencies, handling basic emergencies (if it was not succeed, the referral for further treatment must be prepared), reporting to the Head of UPT, recording in an orderly and complete manner on the patient's medical record. Elective outpatient referrals were given to WBPs who were sick but could not be handled by health services in prisons such as specialist consultations based on indications of illness. This reference was elective or planned and was only for outpatient care by following the applicable referral procedure. Steps for activities were coordinating with outpatient referral facilities, conducting elective outpatient referral procedures, reporting to related structural officials, recording referral results, and further treatment plans on medical records.

\section{The constraints in providing health services}

In providing optimal health care, health personnels who were prison polyclinic doctors have stated the problem faced in providing services to all prisoners was in providing health services regarding the referral to health facilities outside the prisons which required the prisoners to be hospitalized. The limited human resources, especially the guard team or security who have task to assist the hospitalized prisoners caused the prison health personnels to be involved in guarding and working outside their duties, therefore, they would not be able to provide maximum service in the prison polyclinic. The problems in limitations and complicated access to health care could lead to unresolved health care problems in prisons (Harner \& Riley, 2013).

This constraint was in accordance with a study done by Bambang (2017) which explained thatthere were inhibiting factors for the fulfillment of reproductive health rights for female prisoners, even though human resources experienced a lack of health personnels such as obstetricians or midwives, there were no nutritionists in determining the nutritional standard, and there were no expert chef in providing the food.

\section{REFERENCES}

Asfinawati. Jumlah Napi Terus Meningkat Lapas Overkapasitas, Sindo News (accessed 4 Mei 2018) available at: https://nasional.sindonews.com/read /1299409/13/jumlah-napi-terusmeningkat-lapas-overkapasitas-1524199759.

Badan Penelitian dan Pengembangan HAM Departemen Kehakiman dan HAM RI (2003). Pelaksanaan Standard Minimum Rules (SMR) di Lembaga Pema- 
syarakatan. Jakarta: Badan penelitian dan pengembangan HAM Departemen Kehakiman dan HAK RI.

Bambang I (2017). Pemajuan hak atas kesehatan reproduksi bagi perempuan narapidana di lembaga pemasyarakatan klas IIa Sragen, 135-146.

Becker MH, Nancy JK (1997). The Health Belief Model and Personal Health Behavior. Thorofare. New Jersey: Charles B. Slanckinc.

Direktorat Jenderal Pemasyarakatan Kementerian Hukum dan HAM RI (2014). Standar Pelayanan Dasar Perawatan Kesehatan di Lapas, Rutan, Bapas, LPKA dan LPAS (2015). Kementerian Hukum dan Hak Asasi Manusia Republik Indonesia Direktorat Jenderal Pemasyarakatan Direktorat Bina Kesehatan dan Perawatan Narapidana dan Tahanan.

Direktorat Jendral Pemasyarakatan Kementerian Hukum \& HAM (2018). Sistem Database Pemasyarakatan. Ditjen Pemasyarakatan, available at: Smslap.ditjenpas.go.id (accessed 1 May 2018).

Hamid S (2014). Manajemen Sumber Daya Manusia Lanjutan, Yogyakarta: Deepublish.

Harner HM, Riley S (2013). Factors Contributing to Poor Physical Health in Incarcerated Women. Journal of Health Care for the Poor and Underserved, 24(2), 788-801. https://doi.org/10.1353/hpu.2013.0059

Kementerian Hukum dan Hak Asasi Manusia. Peraturan Menteri Hukum dan Hak Asasi Manusia Republik Indonesia Nomor M.HH.02.UM.06.04 tahun 2011. Pedoman Pelayanan Kesehatan di Lingkungan Kementerian Hukum Dan Hak Asasi Manusia. www.djpp.kemenkumham.go.id

Kementrian Hukum dan Hak Asasi Manu- sia Republik Indonesia. Keputusan Direktur Jenderal Pemasyarakatan Kementerian Hukum dan Hak Asasi Manusia Republik Indonesia, Nomor Pas - 498.Pk.01.07.02 Tahun 2015. Standar Penyelenggaraan Makanan di Lembaga Pemasyarakatan, Rumah Tahanan Negara dan Cabang Rumah Tahanan Negara. Direktur Jenderal Pemasyarakatan Kementerian $\mathrm{Hu}-$ kum dan Hak Asasi Manusia Republik Indonesia.

Lindquist CH, Lindquist CA (1999). Health Behind Bars: Utilization And Evaluation Of Medical Care Among Jail Inmates. Journal of Community Health, 24(4): 1-19.

Mertokusumo S (2007). Mengenal Hukum. Cetakan ketiga Edisi lima. Liberty. Yogyakarta.

Ministry of Justice and Human Rights (2014). Prison database system, medical care. available at: www.ditjenpas.go.id/?option $1 / 4$ com_statistik\&tas $\mathrm{k} 1 / 4 \mathrm{ndw}$ (accessed 1 May 2018).

Mubarak WI, Chayatin N (2007). Buku Ajar Kebutuhan Dasar Manusia Teori dan Aplikasi dalam Praktik. Jakarta: penerbitBukuKedokteran EGC. Hal 72.

Nembrini PG (2007). Air, Sanitasi, Higiene, dan Habitat di Lingkungan Lapas dan Rutan. Jakarta; ICRC.

Plugge E, Douglas N, Fitzpatrick AR (2008). Imprisoned women's concepts of health and illness: The implications for policy on patient and public involvement in healthcare. Journal of Public Health Policy, 29(4): 424-439. https://doi.org/10.1057/jphp.2008.32.

Primawardani Y (2017). Perawatan Fisik Terkait Penyediaan Makanan dan Minuman Bagi Narapidana di Lembaga Pemasyarakatan Ditinjau dari 
Journal of Health Policy and Management (2019), 4(1): 1-12

https://doi.org/10.26911/thejhpm.2019.04.01.01

Pendekatan Hak Asasi Manusia (Physical Treatment Related to Food and Beverage Supplies to Convicts at Correctional Institutions Reviewed by Human Rights Approach). Pusat Penelitian dan Pengembangan Hak Asasi Manusia Badan Penelitian dan Pengembangan Hukum dan Hak Asasi Manusia Kementerian Hukum dan Hak Asasi Manusia Republik Indonesia. Jakarta: JIKH. 11(2): 159 179.

Ramidha RS (2011). Evaluasi Sanitasi Lingkungan Institusi Lembaga Pemasyarakatan Klas I Kota Madiun. Skripsi. Fakultas Kesehatan Masyarakat. Universitas Airlangga.

Republik Indonesia, Departemen Kesehatan, UndangUndangNomor 36 Tahun 2009 TentangKesehatan, Jakarta.
Republik Indonesia, Peraturan Pemerintah Nomor 32 Tahun 1999 Tentang Syarat dan Tata Cara Pelaksanaan Hak Warga Binaan.

Republik Indonesia, Undang-UndangDasar Negara Republik Indonesia Tahun 1945.

Republik Indonesia, Undang-Undang Negara Nomor 12 Tahun 1995 Tentang Pemasyarakatan.

Sayrani LP (2017). Diskursus identitas dalam keilmuan administrasi publik. administratio: jurnal ilmiah administrasi publik dan pembangunan. 5(2): 105. Fakultas Fisip Universitas Lampung. Lampung.

Standard Minimum Ruler United Nations for The Treatment of Prisoner, $31 \mathrm{Juli}$ 1957. 